\title{
Bilateral Central Ptosis in Acquired Immunodeficiency Syndrome
}

\author{
Jason J.S. Barton, Randy H. Kardon, Daniel Slagel and H. Stanley Thompson
}

\begin{abstract}
A man with acquired immune deficiency syndrome suddenly developed bilateral complete ptosis and minor vertical gaze limitation. Magnetic resonance imaging revealed a lesion in the midbrain surrounding the sylvian aqueduct in addition to bilateral masses in the caudate nuclei. Pathologic examination showed that the caudate lesions were central nervous system lymphoma of B cell origin, but the midbrain lesion contained only signs of AIDS encephalopathy. The periaqueductal lesion involved the caudal central subnucleus and probably also the subnuclei of the superior and inferior recti of the oculomotor nuclear complex bilaterally.
\end{abstract}

\begin{abstract}
RÉSUMÉ: Ptôsis bilatéral d'origine centrale chez un homme atteint du syndrome d'immunodéficience acquise: correlation clinique et radiologique. Nous décrivons le cas d'un homme atteint du syndrome d'immunodéficience acquise qui a développé subitement un ptôsis bilatéral complet et une parésie du regard vers le haut. L'imagerie par résonance magnétique a révélé la présence d'une lésion du mésencéphale entourant l'aqueduc de Sylvius ainsi que des masses bilatérales dans le noyau caudé. L'examen anatomopathologique a montré que les lésions des noyaux caudés étaient un lymphome originant de cellules B, mais que les lésions du mésencéphale ne présentaient que des signes d'encéphalopathie du SIDA. La lésion située autour de l'aqueduc impliquait également le sous-noyau central du nerf moteur oculaire commun et probablement aussi les sous-noyaux des droits supérieur et inférieur du complexe nucléaire oculomoteur bilatéral.
\end{abstract}

Can. J. Neurol. Sci. 1995; 22: 52-55

Bilateral blepharoptosis is a sign most commonly associated with myopathies of diseases affecting the neuromuscular junction. It is only infrequently caused by lesions within the central nervous system: most of the reported cases are due to brainstem infarcts affecting the levator subnucleus within the oculomotor nuclear complex in the midbrain..$^{1-6}$ We report the case of a man with acquired immunodeficiency syndrome who suddenly developed bilateral ptosis.

\section{CASE Report}

A 39-year-old man awoke with a severe frontal headache and inability to open his eyes. The headache resolved after 12 hours but the difficulty opening his eyes remained over the next three weeks. Neither he nor his family noted any fluctuation in the position of his lids. When he opened his eyes with his fingers he noticed a mild intermittent vertical diplopia. He denied problems with swallowing, speech, or limb strength. A computed tomographic (CT) scan showed bilateral masses in the region of the heads of the caudate nuclei. Dilantin, sulfadiazine and pyramethamine were started for possible cerebral toxoplasmosis.

His past history included a positive test for antibodies and human immunodeficiency virus type 1 . He had suffered from herpes simplex viral proctitis. His other medications included acyclovir, pentamidine, and dideoxyinosine. He had stopped taking hydromorphone the day previous to his visit. Recent laboratory results included a peripheral white cell count of 3.5 with a low lymphocyte count of 770; his absolute T4 cell count was reduced significantly at $31 \mathrm{~mm}^{3}$. His cerebrospinal fluid a week priviously had contained three lymphocytes and elevated protein but normal glucose and cytology.

He had complete bilateral ptosis. He saw by tilting his head back and contracting his frontalis. No blepharospasm was witnessed. Pursuit and saccadic movements were reduced only slightly in upgaze but moderately in downgaze, more so in the right eye. The range of movement did not increase with vestibular manoeuvers. Horizontal pursuit and saccades were full and there was no internuclear ophthalmoplegia. Convergence was present and no nystagmus was seen. Pupils were small, possibly due to narcotics, but showed good light reactivity and near response. There was no relative afferent pupillary defect and confrontation fields were full. Fundoscopy showed no retinitis. He had no facial weakness or sensory deficit and the rest of his neurologic examination was normal.

A magnetic resonance (MR) scan was done that day (Figure 1). There were bilateral enhancing lesions involving the caudate nuclei bilaterally. In the midbrain there was a ring of enhancement surrounding the sylvian aqueduct and the same region possessed high signal intensity on T2-wieghted images.

He was continued on therapy for possible toxoplasmosis and dexamethasone was added. An MR scan one week later showed no change. By two weeks there was some improvement in his ptosis and range of vertical eye movement. His pupils now were $3 \mathrm{~mm}$ bilaterally in light with good light reactivity and near response.

A stereotactic biopsy of one of the caudate lesions 24 hours after his initial assessment revealed a large cell lymphoma, which proved to be of B-cell origin by immunocytochemistry. Four days after his second examination he died of aspiration.

Neuropathologic examination showed large cell lymphoma involving the head of the caudate nuclei, right more than left, with right-sided extension to the caudate body and tail as well as the putamen and anterior limb of the internal capsule. Frontal cortex was not involved. There was an area of softening and discoloration surrounding the aqueduct (Figure 2A). On microscopy this area contained diffuse and perivascular

From the Department of Ophthalmology (J.J.S.B., R.H.K., H.S.T.) and Pathology (D.S.), University of lowa Hospitals and Clinics, Iowa City, Iowa.

RECEIVED JULY 20, 1993. ACCEPTED IN FINAL FORM SEPTEMBER 30, 1994.

Reprint requests to: Dr. J.S. Barton, Division of Neurology, The Toronto Hospital, 399 Bathurst Street, Toronto, Ontario, Canada M5T 2S8 

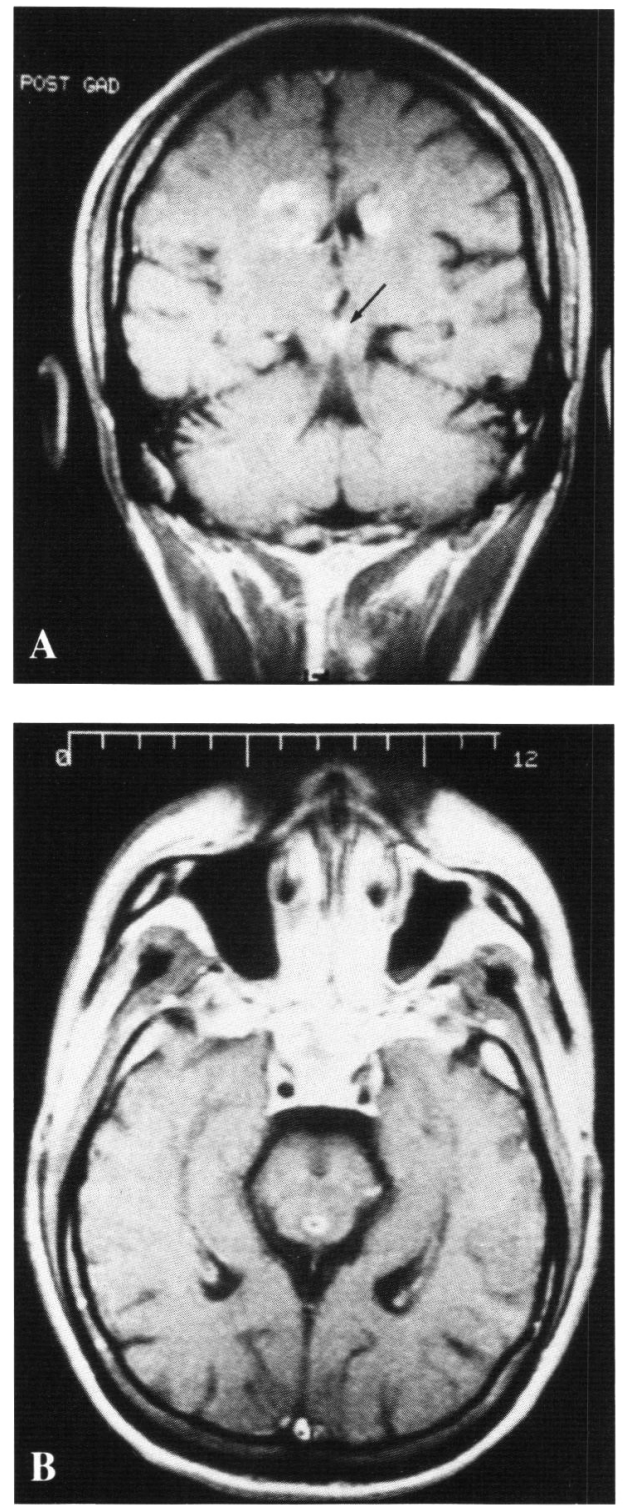

Figure 1: Gadolinium-enhanced Tl-weighted images of the periaqueductal lesion in axial and coronal planes. Note also the bilateral enhancing caudate lesions on the coronal image.

lymphocytic infiltrates with microglial nodules, concentric edema, and multinucleate giant cells, distinctly different from his caudate lymphoma, and which involved the oculomotor nuclei bilaterally (Figure 2B). No viral inclusions were seen and special stains for fungi, bacteria and mycobacteria were negative. Immunohistochemical staining for cytomegalovirus was negative in this region.

\section{Discussion}

Warwick's anatomic scheme ${ }^{7}$ of the third nerve nuclear complex, obtained through studying the chromatolysis after muscle extirpation, was refined recently by Henn et al. using retrograde labelling with horseradish peroxidase. ${ }^{8}$ Both levator palpebrae superiori are innervated by the caudal central subnucleus, a single dorsal midline structure (Figure 3). Therefore isolated bilateral ptosis could occur with a lesion placed medially, caudally and dorsally. Ventral extension of such a lesion would impinge upon the paired subnuclei of the vertical recti. The findings of

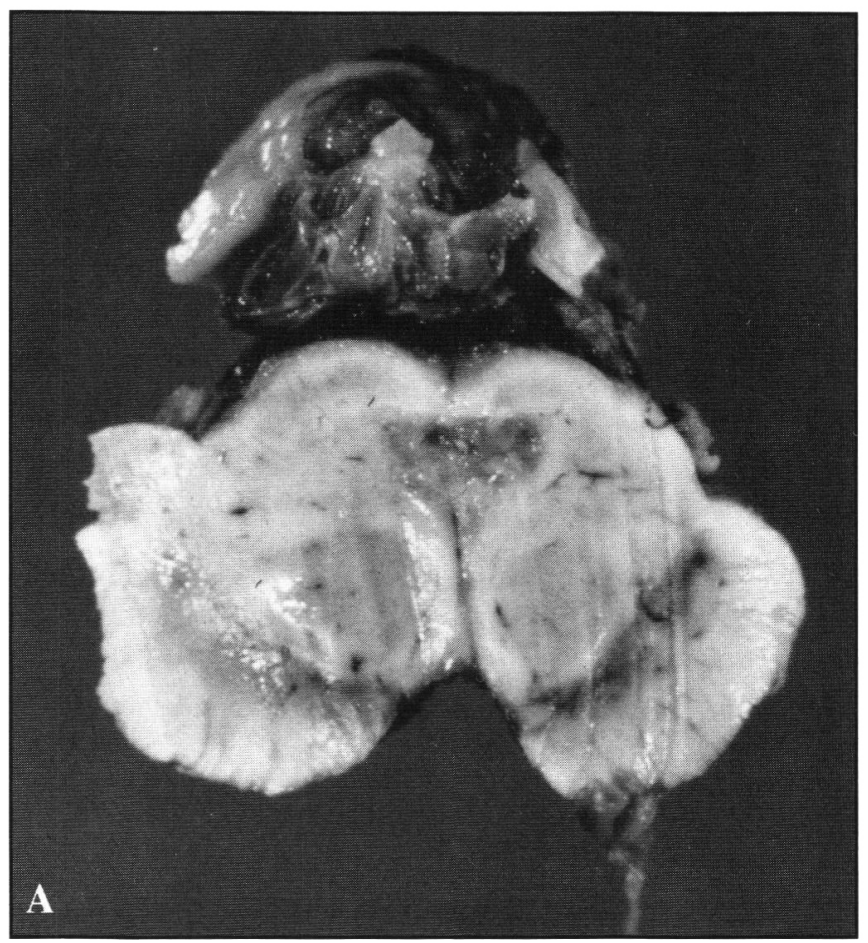

Figure 2A: Gross axial section, showing periaqueductal softening and edema.

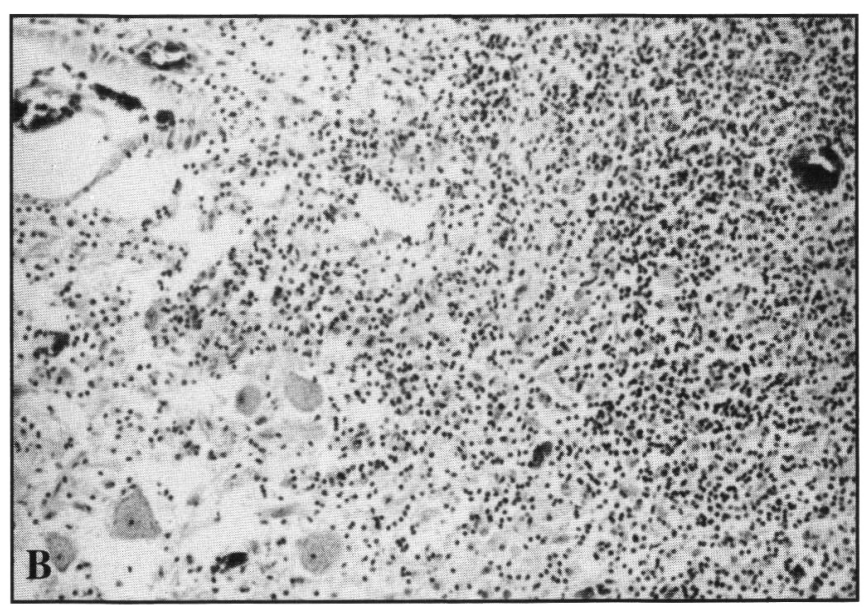

Figure 2B: Hematoxylin and eosin stain showing marked lymphocytic infiltration involving the caudal central subnucleus at the lower left.

Henn et al. suggest that the subnuclei for the inferior recti would be more likely and earlier affected than those for the superior recti. ${ }^{8}$ The pupil would be spared unless the lesion extended rostrally to the Edinger-Westphal nucleus.

We believe that the ring of enhancement and high signal around the aqueduct on MR imaging is evidence of such a lesion in our patient. The ventral aspect of this ring would impinge on the caudal central subnucleus, with further extension affecting the inferior recti subnuclei on either side, resulting in complete bilateral symmetric ptosis and mildly asymmetric paresis of downgaze more than upgaze, but preserved horizontal movements and pupil function. The lack of improvement of ocular vertical range with vestibular manoeuvers may occur with either 


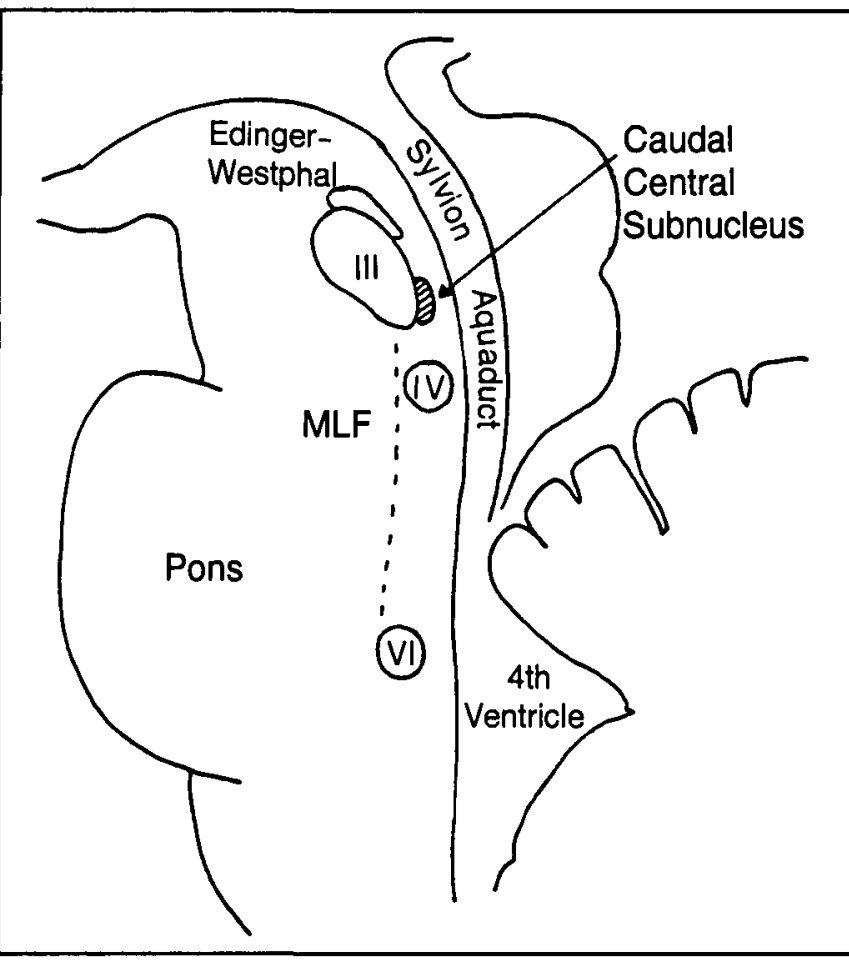

Figure 3: Diagram of sagittal section through the brainstem, showing the ocular motor nuclei. Caudal central subnucleus is shaded: note its dorsal relation to the other III nerve subnuclei and its proximity to the aqueduct. nuclear or extensive supranuclear dysfunction; the asymmetry argues for at least some nuclear involvement.

An alternative explanation of ptosis is suggested by the bilateral lesions in the caudate nuclei anteriorly. Bilateral 'cerebral ptosis' has been described with non-dominant or bilateral lesions of the frontal lobes. ${ }^{9-11}$ However, most of these cases had partial $^{9}$ or asymmetric ${ }^{10}$ ptosis, whereas our patient had complete symmetric bilateral ptosis. The limitations of vertical gaze also suggested midbrain rather than hemispheric dysfunction.

The selective involvement of various portions of oculomotor nerve function by a nuclear lesion has been described. Sparing of the caudal central subnucleus in an otherwise complete third nerve palsy with pupillary involvement has been reported at least twice. ${ }^{12,13}$ The converse, bilateral ptosis with sparing of other third nerve function, was first reported by Stevenson and Hoyt. ${ }^{14}$ Right internuclear ophthalmoplegia and 'weak' convergence were the only other initial signs but subsequent involvement of convergence, upgaze, and pupil light reactivity occurred prior to autopsy, which showed a large metastatic nodule in the midbrain.

Five other cases with pathologic examination have been described. Two were infarcts with other neuro-ophthalmologic signs such as unilateral third nerve palsy, ${ }^{1,15}$ absent pupillary light reflexes and horizontal gaze paralysis. ${ }^{4}$ Conway et al. described one case of relatively isolated bilateral ptosis, ${ }^{3}$ where only convergence insufficiency, vertical gaze-evoked nystagmus and facial palsy developed prior to death; the central caudate subnucleus was involved by encephalitis on autopsy.

Table. Literature review: associated signs at onset of central bilateral ptosis.

\begin{tabular}{|c|c|c|c|c|c|c|c|c|c|}
\hline Case & Etiology & $\begin{array}{c}\text { Pupil } \\
\text { light reflex }\end{array}$ & $\begin{array}{l}\text { Range of eye } \\
\text { movement }\end{array}$ & $\begin{array}{c}\text { Internuclear } \\
\text { ophthalmoplegia }\end{array}$ & Convergence & Nystagmus & $\begin{array}{c}\text { Other neurologic } \\
\text { signs }\end{array}$ & Imaging & Pathology \\
\hline Stevenson ${ }^{14}$ & metastasis & normal & normal & right & weak & none & none & no & yes \\
\hline Bogousslavsky ${ }^{6}$ & infarct & normal & $\begin{array}{l}\text { left superior } \\
\text { rectus palsy }\end{array}$ & right & weak & $\begin{array}{l}\text { gaze-evoked } \\
\text { in upgaze }\end{array}$ & none & $\mathrm{CT}$ & no \\
\hline Conway $^{3}$ & encephalitis & $?$ & normal & no & insufficiency & none & none & no & yes \\
\hline Biller $^{5}$ & infarct & normal & impaired upgaze & bilateral & $?$ & $\begin{array}{l}\text { convergence- } \\
\text { retraction }\end{array}$ & somnolence & $\mathrm{CT}$ & no \\
\hline Dehaene $^{4}$ & infarct & $\begin{array}{c}\text { absent } \\
\text { OU }\end{array}$ & $\begin{array}{c}\text { horizontal gaze } \\
\text { palsy }\end{array}$ & no & $?$ & $\begin{array}{l}\text { right eye } \\
\text { bobbing }\end{array}$ & $\begin{array}{c}\text { tetraplegia } \\
\text { decerebrate } \\
\text { rigidity }\end{array}$ & no & yes \\
\hline Büttner-Ennever ${ }^{16}$ & glioma & normal & $\begin{array}{l}\text { supranuclear palsy } \\
\text { of downgaze }\end{array}$ & no & absent & gaze-evoked & $\begin{array}{l}\text { drowsiness } \\
\text { ataxia }\end{array}$ & $\mathrm{CT}$ & yes \\
\hline Brasil-Netro ${ }^{18}$ & hemorrhage & miosis & $\begin{array}{l}\text { impaired upgaze } \\
\text { poor right pursuit }\end{array}$ & $?$ & $?$ & $?$ & somnolence & $\mathrm{CT}$ & no \\
\hline $\operatorname{lwanaga}^{17}$ & hemorrhage & $?$ & diplopia & $?$ & $?$ & $?$ & $?$ & $\mathrm{MR}, \mathrm{CT}$ & no \\
\hline ours & encephalitis & normal & $\begin{array}{l}\text { impaired } \\
\text { downgaze }\end{array}$ & no & normal & none & none & MR & yes \\
\hline
\end{tabular}


Büttner-Ennever et al. had a case similar to ours, with a periaqueductal glioma causing central ptosis and supranuclear downgaze paralysis; ${ }^{16}$ however, many of the central caudate neurons had survived, suggesting that the disturbance of levator function was also supranuclear.

Eight reports of imaging in patients with central bilateral ptosis exist. Meienberg et al. were not able to demonstrate the lesion with the CT technology available in $1979 .^{2}$ Lesions on CT scans were found in the other cases..$^{5,6.15-19}$ We found only one other report of MR imaging in this condition. ${ }^{17}$

Many of the previously reported cases are not of isolated ptosis but of a mixture of ocular motor signs of nuclear or tract dysfunction (Table). Vertical gaze is often affected, ${ }^{1.5 .6}$ at a nuclear level given the proximity of the subnuclei for the superior and inferior recti to the caudal central subnucleus, although examples of supranuclear palsies exist. ${ }^{6}$ Internuclear ophthalmoplegia is also common as the medial longitudinal fasciculus ascends nearby in the dorsal midline..$^{5,6.14}$ Several cases also have evidence of more widespread brainstem disease, limiting their localizing value. ${ }^{1,2,4,5}$ Somnolence in particular is a common accompanying sign.

Our case offers the advantage of a circumscribed neurologic deficit due to a small periaqueductal lesion localized with the high resolution of MR imaging and confirmed on pathologic examination. We are not aware of other reports of central ptosis with acquired immune deficiency syndrome. The pathology was consistent with direct cytopathic effect of HIV infection. ${ }^{20}$ The clinical findings are consistent with experimental data showing a single dorsal and caudal midline nucleus for the levator palpebrae superiori which is adjacent to the subnuclei for vertical recti but more caudal to the visceral nucleus serving pupillomotor function.

\section{REFERENCES}

1. Growdon JH, Winkler G, Wray SH. Midbrain ptosis. A case with clinicopathologic correlation. Arch Neurol 1974; 30: 179-181.

2. Meienberg $\mathrm{O}$, Mumenthaler M, Karbowski K. Quadriparesis and nuclear oculomotor palsy with total bilateral ptosis mimicking coma. Arch Neurol 1979; 36: 708-710.
3. Conway VH, Rozdilsky B, Schneider RJ, Sundaram M. Isolated bilateral complete ptosis. Can J Opthalmol 1983; 18: 37-40.

4. Dehaene I, Dom R, Marchau M, Geens K. Locked-in syndrome with bilateral ptosis: combination of bilateral horizontal pontine gaze paralysis and nuclear oculomotor nerve paralysis. J Neurol 1985; $232: 366-367$.

5. Biller J, Shapiro R, Evans LS, Haag JR, Fine M. Oculomotor nuclear complex infarction. Clinical and radiological correlation. Arch Neurol 1984; 41: 985-987.

6. Bogousslavsky J, Regli F, Ghika J, Hungerbühler JP. Internuclear ophthalmoplegia, prenuclear paresis of contralateral superior rectus, and bilateral ptosis. J Neurol 1983; 230: 197-203.

7. Warwick R. Representation of the extra-ocular muscles in the oculomotor nuclei of the monkey. J Comp Neurol 1953; 98: 449-504.

8. Henn V, Büttner-Ennever JA, Hepp K. The primate oculomotor system I. Motoneurons. Human Neurobiol 1982; 1: 77-85.

9. Krohel GB, Griffin JF. Cortical blepharoptosis. Am J Opthalmol 1978; 85: 632-634.

10. Caplan LR. Ptosis. J Neurol Neurosurg Psychiatry 1974; 37: 1-7.

11. Nutt JG. Lid abnormalities secondary to cerebral hemisphere lesions. Ann Neurol 1977; 1: 149-151.

12. Keane JR, Zaias B, Itabashi HH. Levator-sparing oculomotor nerve palsy caused by a solitary midbrain metastasis. Arch Neurol 1984; $41: 210-212$.

13. Elliott RL. Encephalitis with ophthalmoplegia. Confin Neurol 1969; 31: 194-197.

14. Stevenson GC, Hoyt WF. Metastasis to midbrain from mammary carcinoma. Cause of bilateral ptosis and ophthalmoplegia. JAMA 1963; 186: 514-516.

15. Zackon DH, Sharpe JA. Midbrain paresis of horizontal gaze. Ann Neurol 1984; 16: 495-504.

16. Büttner-Ennever JA, Acheson JF, Büttner U, Graham EM, Leonard TJK, et al. Ptosis and supranuclear downgaze paralysis. Neurology 1989; 39: 385-389.

17. Iwanaga K, Kinoshita I, Nobuharu O. Brainstem ptosis (midbrain ptosis) associated with mesencephalic hemorrhage. Rinsho Shinkeigaku 1990; 30: 793-795.

18. Brasil-Neto JP, Tosta ED, Henriques FG. Ptose palpebral bilateral com paralisia unilateral do olhar vertical para cima. Arquiv Neuro-psiquiatria 1986; 44: 82-88.

19. Bril V, Sharpes JA, Ashby P. Midbrain asterixis. Ann Neurol 1979; 6: $362-364$.

20. Kato T, Hirano A, Llenal JF, Demlitzer HM. Neuropathology of acquired immune deficiency syndrome (AIDS) in 53 autopsy cases with particular emphasis on microglial nodules and multinucleated giant cells. Acta Neuropathologica 1987; 73: 287297. 